\title{
NOMA Superiority Condition for Rayleigh Fading Channels
}

\author{
Enis KÖRPE ${ }^{1}$, Bilge KARTAL ÇETIN ${ }^{2}$ \\ ${ }^{1,2}$ Department of Electrical and Electronics Engineering, Faculty of Engineering, Ege University, İzmir, \\ Turkey \\ $\bowtie$ : bilge.kartal@ege.edu.tr, (iD)10000-0001-8271-9059, (iD220000-0002-3338-1538
}

Received (Geliş): 25.04.2021Ｒevision (Düzeltme): 31.05.2021Ａccepted (Kabul): 06.06.2021

\begin{abstract}
Non-orthogonal Multiple Access (NOMA) is a new generation multiple access technique in which multiple users simultaneously share the same frequency band. In the implementation of NOMA, the choice of user pairs that will use the same frequency is a determining factor for the NOMA superiority condition due to Successive Interference Cancellation (SIC) mechanism on the receiver. However, performance of NOMA depends on SIC mechanism which relies on the order of the user in a NOMA cluster. In the literature, it has been shown that utilizing distance based order of the users for user pairing outperforms over the random pairing and an analytical boundary distance is derived for NOMA superiority condition for a path loss based channel model. In this study, the path loss based NOMA superiority condition respect to the Orthogonal Multiple Access (OMA) was investigated in terms of the spectral efficiencies for Rayleigh channel model in a cellular uplink and the results were compared with an analytical boundary value derived for a path loss based channel model in the literature. In addition, the effect of power ratio of the users on the NOMA superiority condition is investigated and accuracy of the derived analytical model is validated with numerical results for both channel models. The results reveal that the NOMA superiority condition based on distance changes depend on the assumed channel model, but assuming the channel as Rayleigh fading or path loss based channel does not make a significant difference. In addition, it is observed that the accuracy of the derived NOMA superiority condition changes with the power ratios for both channel models and the gap between numerical and analytical results is larger in Rayleigh channel compared to path loss based channel model.
\end{abstract}

Keywords: Cellular uplink, non-orthogonal multiple access, NOMA superiority condition.

\section{Rayleigh Sönümlemeli Kanalda NOMA Üstünlük Koşulunun Belirlenmesi}

\section{ÖZ}

Dikgen olmayan çoklu erişim (NOMA) birden fazla kullanıcının aynı frekans bandını aynı anda kullanması ilkesine dayanan yeni nesil çoklu erişim tekniğidir. NOMA uygulamasında alıcı üzerindeki Ardışık Girişim İptali (SIC) mekanizması nedeniyle aynı frekansı kullanacak kullanıcı çiftlerinin seçimi NOMA üstünlük durumu için belirleyici bir faktördür. Ancak NOMA'nın performansı, bir NOMA kümesindeki kullanıcının sırasına dayanan SIC mekanizmasına bağlıdır. Literatürde, kullanıcı eşleştirmesi için kullanıcıların mesafe tabanlı sıralamasının kullanılmasının rastgele eşleştirmeden daha iyi performans gösterdiği ve yol kaybı tabanlı bir kanal modeli varsayımıyla NOMA üstünlük koşulu için analitik bir sınır mesafesinin türetildiği gösterilmiştir. Bu çalışmada, NOMA’nın dikgen çoklu erişime (OMA) göre üstünlük koşulu hücresel yukarı yönlü bağlantıdaki Rayleigh kanal modeli için spektrum verimliliği açısından incelenmiş ve yol kaybı temelli kanal modeliyle karşılaştırılmıştır. Bu çalışmada, Dikey Çoklu Erişim'e (OMA) göre yol kaybına dayalı NOMA üstünlük koşulu, bir hücresel yukarı bağlantıda Rayleigh kanal modeli için spektral verimlilikler açısından araştırılmış ve sonuçlar, literatürdeki yol kaybı tabanlı kanal modeli için türetilen bir analitik sınır değeri ile karşılaştırılmıştır. Ayrıca, kullanıcıların güç oranının NOMA üstünlük koşuluna etkisi araştırılmış ve türetilen analitik modelin doğruluğu, her iki kanal modeli için sayısal sonuçlarla doğrulanmıştır. Sonuçlar, mesafe değişikliklerine dayalı NOMA üstünlük koşulunun varsayılan kanal modeline bağlı olduğunu, ancak kanalı Rayleigh sönümleme veya yol kaybı tabanlı kanal olarak kabul etmenin önemli bir fark yaratmadığını ortaya koymaktadır. Ayrıca, her iki kanal modeli için de elde edilen NOMA üstünlük koşulunun doğruluğunun güç oranları ile değiştiği ve Rayleigh kanalında sayısal ve analitik sonuçlar arasındaki farkın yol kaybı tabanlı kanal modeline göre daha büyük olduğu görülmüştür.

Anahtar Kelimeler: Hücresel yukarı yönlü bağlantı, dikgen olmayan çoklu erişim, NOMA üstünlük koşulu 


\section{INTRODUCTION}

In the past few decades of the cellular communication development, Frequency division multiple access (FDMA), time division multiple access (TDMA) and code division multiple access (CDMA) were utilized as the orthogonal channel access techniques in $1 \mathrm{G}, 2 \mathrm{G}$ and $3 \mathrm{G}$, respectively. In Long-Term Evolution (LTE) (4G) and LTE-Advanced (4.5G), orthogonal frequency division multiple access (OFDMA) is adopted as the Orthogonal Multiple Access (OMA) method [1]. In OMA, orthogonal frequencies are assigned to cellular users, therefore there is no mutual interference between users and this enables to use simplified receivers. OMA schemes are sufficient for system-level throughput, but high traffic demands of future $5 \mathrm{G}$ network have led to search alternative channel access mechanisms for improved spectral efficiency [2, 3] NOMA is seen as a promising candidate as a multiple access technique for the spectral performance improvement in next-generation cellular communications. In NOMA, multiple users simultaneously share the same frequency band [3, 4]. In [5], the results show that NOMA provides $30 \%$ more throughput than OMA counterpart. In addition, NOMA provides an efficient way to increase the user fairness [6].

The operating principle of NOMA has a mechanism called SIC at the receiver where decoding is done successively. In SIC, the weakest signal can be extracted by subtracting stronger inter-user interferences with superposition coding [7]. NOMA increases spectral efficiency using SIC mechanism [8]. The SIC technique is applied differently in uplink and downlink;

In uplink (at top in Figure 1), the base station (BS) first decodes the signal of the cell center user $\left(\mathrm{U}_{1}\right)$ with a large channel gain $\left(\left|\mathrm{h}_{1}\right|^{2}\right)$.

Because, for the cell center user the received signal power at BS is likely to be the stronger at the $\mathrm{BS}$ as it has the stronger channel gain compared to the cell edge user. In this step, the signal of the cell edge user $\left(\mathrm{U}_{2}\right)$ with weak channel gain $\left(\left|h_{2}\right|^{2}\right)$ is considered as interference.

In the second step, the BS decodes the signal of the cell edge user with a weak channel gain $\left(\left|h_{2}\right|^{2}\right)$ after subtracting the signal of the strong user from the received superimposed signal.

In downlink (at bottom in Figure 1), the base station allocates more power to the weak user $\left(\mathrm{U}_{2}\right)$ than the strong user $\left(\mathrm{U}_{1}\right)$. The strong user

implements SIC and decodes its own signal. According to the power allocation at the base station, this signal is much weakened to the user $\left(\mathrm{U}_{2}\right)$ having a weak channel gain $\left(\left|\mathrm{h}_{2}\right|^{2}\right)$ because the signal of the strong user $\left(\mathrm{U}_{1}\right)$ is sent at low power. In this way, the weak user $\left(\mathrm{U}_{2}\right)$ could decode the signal at the interference of the strong user $\left(\mathrm{U}_{1}\right)$.

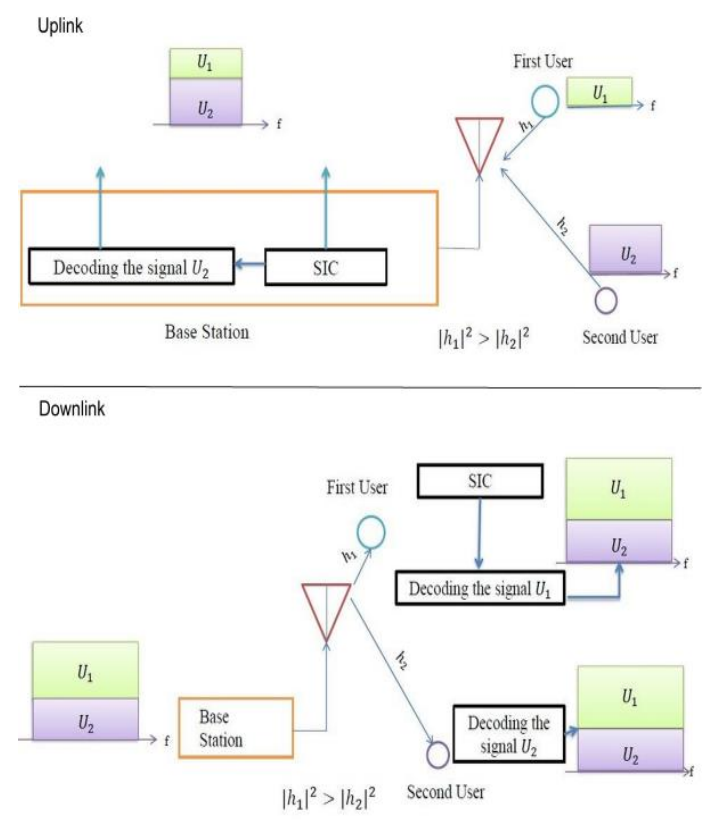

Figure 1. Implementation of SIC in NOMA in uplink and downlink

NOMA superiority condition is one of the popular research topics. The conditions that NOMA ensures better spectral efficiency than OMA is called NOMA superiority condition. In NOMA, the selection of user pairs that is going to share the channel is a crucial factor for NOMA superiority condition due to the SIC mechanism applied at the receiver. In addition, interferences values depend on the power allocation and it is done based on user order inside a NOMA cluster but follows an opposite principle of water-filling mechanism. The most of the literature utilize a distance based ordering of the users due to its less complexity and analytical tractability [9-15]. In [9], NOMA and OMA spectrum efficiencies were compared according to their distance from the base station (BS) and the NOMA superiority condition was derived for both users assuming only a basic channel model where the channel gain depends a distance based channel model (path loss model). In [13], the mean rate coverage probability per cluster was calculated for NOMA and OMA respect to the radius of a cluster and NOMA superiority condition was obtained in terms of the average rate coverage.

In this paper, different than the study in [9], we investigate the spectral efficiency for Rayleigh fading channels and compare it with the basic 
channel model to determine whether it affects NOMA superiority conditions. Accuracy of the user ranking based on distance is investigated in [16] and it is concluded that for two user NOMA clusters it is reasonable to use distance based ordering of the user for Rayleigh channels. Specifically, the role of the user distances from base station for NOMA superiority condition for Rayleigh channels is investigated for the selection of user pairs that share the same channel in the cellular uplink. (Preliminary results of this study have been presented in [17]). In fact, the NOMA is always superior to OMA in terms of the sum spectral efficiency. However, each individual user's spectral efficiency needs to be investigated in terms of NOMA superiority conditions as well as the sum spectral efficiency. The Main contribution of this work is two folds; i) It has been shown in [9] that the distance based user pair selection conditions for two user NOMA cluster is significance compared to the random user pairing. We investigates whether distance based conditions for NOMA superiority derived for the basic channel model in [9] is valid for Rayleigh fading channels and if so how much the results differ from the conditions derived for the basic channel model.

ii) As the power allocation is crucial for the performance of NOMA, we investigate the effect of power ratios on NOMA superiority conditions. To the best of our knowledge, in the current literature [9, 13-18] about the NOMA superiority, where a distance based ranking of the users are utilized as a link quality metrics, neither the power control nor the effect of power ratios has not been considered. We also evaluate the accuracy of the derived boundary distance for NOMA superiority for different power ratios.

It has been shown that for both channels, the selection of user pairs is important for the NOMA superiority condition to be valid for both users.

\section{METHODOLOGY and SYSTEM MODEL}

We consider a scenario where uplink channel is shared by two user with NOMA principle. We implemented the scenario in MATLAB. We assume that a base station runs SIC mechanism to decode the superimposed signal of two users. It is assumed that the first user has always stronger channel. Therefore, the base station decodes the first user's signal by treating the second user's interference as noise. However, the base station decodes the second user's signal after subtracting the first user's decoded signal from the superimposed signal. Hence, the second user's signal is decoded without any interference caused by the first user. The spectral efficiencies for NOMA and OMA users ( $\mathrm{C}^{\text {NOMA }}$ andC ${ }^{\text {ONA }}$ ) are calculated using Shannon formula in
Equation 1, 2 and 3. The channel gains $\left(\left|h_{i}\right|^{2}\right)$ for two channel models are calculated through Equations 4 and 5.

$$
\begin{gathered}
C_{1}^{[\text {NONA })}=\log _{2}\left(1+\frac{P_{1} *\left|h_{1}\right|^{2}}{P_{2} *\left|h_{2}\right|^{2}+N_{0}}\right) \\
C_{2}^{[\text {NONA })}=\log _{2}\left(1+\frac{P_{2} *\left|h_{2}\right|^{2}}{N_{0}}\right. \\
C_{i}^{[O N A)}=0.5 * \log _{2}\left(1+\frac{P_{1} *\left|h_{i}\right|^{2}}{N_{0}}\right) \\
\left|h_{\mathrm{i}}\right|_{\text {basicchannel }}^{2}=\left(d_{i}\right)^{-a} \\
\left|h_{i}\right|_{\text {Rayleighfading }}^{22}=\exp \left(d_{i}\right)^{-a}
\end{gathered}
$$

where $P_{1}$ and $P_{2}$ are transmission powers and $\mathrm{N}_{0}$ is the power spectral density of the Gaussian noise at the BS. The distance between the BS and $i^{\text {th }}$ user is represented as $\mathrm{d}_{\mathrm{i}}$ and $a$ is the common path loss component. In Equation 3, similar to [9], we consider a TDMA based OMA where the uplink channel is allocated to each user half of the duration at which the BS serves the users, the multiplier 0.5 is used to represent this behavior. Equation 4, for the basic channel model the channel gain $\left(\left|h_{i}\right|^{2}\right)$ is described as a simplified distance dependent path loss model. Equation 5 describes an exponential distributed channel coefficient when the channel is assumed as Rayleigh fading. The limit distances at which NOMA superior to OMA is calculated by applying the following condition [9]:

$\mathrm{C}_{\mathrm{i}}^{(\text {NOMA })}>\mathrm{C}_{\mathrm{i}}^{[\text {(ONA) }}{ }_{*} \mathrm{\forall}_{\mathrm{i}}=1,2$

Utilizing Equation 6, the necessary condition that guaranties the superiority of NOMA over OMA is determined $a s d_{2}>d_{1}$ and $d_{2}>d_{\text {lim }}$, where user 1 (having good channel) located at $d_{1}$, while the user 2 (having poor channel) is located at $d_{2}$. Then the value of $d_{\lim }$ is derived as follows [9],

$\mathrm{d}_{\mathrm{lim}}=\left(\frac{\sqrt{1+\mathrm{P}_{\mathrm{NI}} \mathrm{d}_{1}{ }^{-\mathrm{a}}}}{P_{\mathrm{N} 2}}\right)^{-\frac{1}{\mathrm{a}}}$ 
where $\mathrm{P}_{N 1}$ and $P_{N 2}$ denote the transmit power of strong and weak user normalized by the $\mathrm{N}_{0}$.

This result is derived by substituting Equation 4 into Equation 1,2 and 3.

\section{RESULTS and DISCUSSION}

Results are obtained for spectral efficiencies averaging over 1000 random networks. The cell-center user and the cell-edge user were referred to as strong user and weak user, respectively, and their distances to the base station were expressed as $\mathrm{d}_{1}$ and $\mathrm{d}_{2^{x}}$ respectively. Numerical values are presented in Table 1. Note that in NOMA power allocation to the user does not follow the water-filling principle because of the SIC mechanism at the receiver. Instead, the user with poor channel is allocated more power while the user having strong channel transmit with less power. For the numerical analysis we choose an arbitrary ratio of 0.8 and set the users' transmission (Tx) power accordingly, later we investigate the NOMA superiority condition for different power ratios as well.

Tablo 1. The numerical values

\begin{tabular}{|c|c|}
\hline Parameters & Value \\
\hline Noise power $\left(\mathrm{N}_{0}\right)$ & $10^{-10} \mathrm{~W} / \mathrm{Hz}$ \\
\hline Total tx power $\left(\mathrm{P}_{\mathrm{t}}\right)$ & $0.2 \mathrm{~W}$ \\
\hline Path loss exponent (a) & 4 \\
\hline Tx power of the user $1\left(\mathrm{P}_{1}\right)$ & $0.089 \mathrm{~W}$ \\
\hline $\begin{array}{l}\text { Tx power of the user } 2\left(\mathrm{P}_{2}\right) \\
\text { Tx Power ratio of the users }\left(\mathrm{P}_{1} / \mathrm{P}_{2}\right)\end{array}$ & $\begin{array}{l}0.111 \mathrm{~W} \\
0.8\end{array}$ \\
\hline
\end{tabular}

We investigated NOMA superiority conditions for a scenario where the strong user is located at a reference distance $\left(\mathrm{d}_{1}\right)$ from the BS while the weak user is located at a distance of $d_{2}$. We calculated the spectral efficiency value as a function of the weak user's distance from the base station $\left(\mathrm{d}_{2}\right)$. The illustration of the scenario is shown in Figure 2.

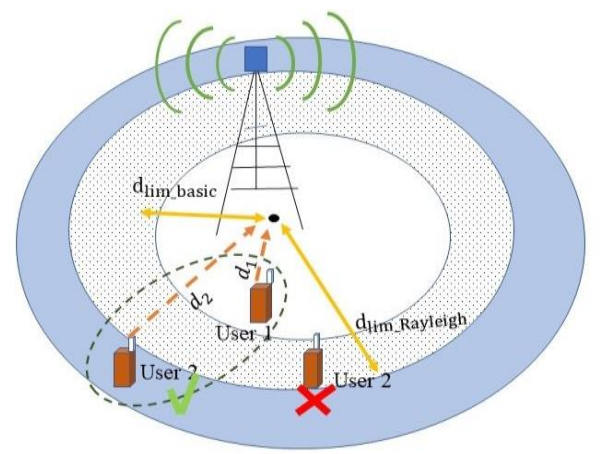

Figure 2. NOMA dominant condition $\left(d_{2}>d_{\text {lim }}\right)$ for user 1 for the Path Loss based Channel model [9] and Rayleigh Channel model $\left(\mathrm{d}_{1}=30 \mathrm{~m}\right)$
OMA and NOMA uplink spectral efficiencies were calculated for the distance values of cell-edge user (weak user, $\left(\mathrm{d}_{2}\right)$ ) which follows the condition of $\mathrm{d}_{1}<\mathrm{d}_{2}$. By selecting a strong user with $d_{1}=30 \mathrm{~m}$ at a fixed reference point, the limit value $\left(\mathrm{d}_{\text {lim }}\right)$ of the weak user's distance is determined for the NOMA superiority condition. The results are shown in Figure 3 and Figure 4.

In Figure 3, it can be seen that for a strong user at a distance of $\mathrm{d}_{1}=30 \mathrm{~m}, \mathrm{~d}_{2}>d_{\text {lim }}=77 \mathrm{~m}$ is NOMA superiority condition for the first user. Note that $d_{l i m}$ value that is found by Equation 8 is $76 \mathrm{~m}$, there is a $1 \mathrm{~m}$ gap between numerical results and the derived analytical limit distance (Equation 8). Therefore, the second user sharing the channel with NOMA principle should be chosen as farther distance of $77 \mathrm{~m}$ from the base station. As the distance $d_{2}$ is increased, SINR (signal-to-interference-plus-noise ratio) of the weak user decreases and its interference to the strong user decreases, so SINR and spectral efficiency of the strong user increase. However, as can be seen from the Figure 3 NOMA is always superior to OMA for the weak user.

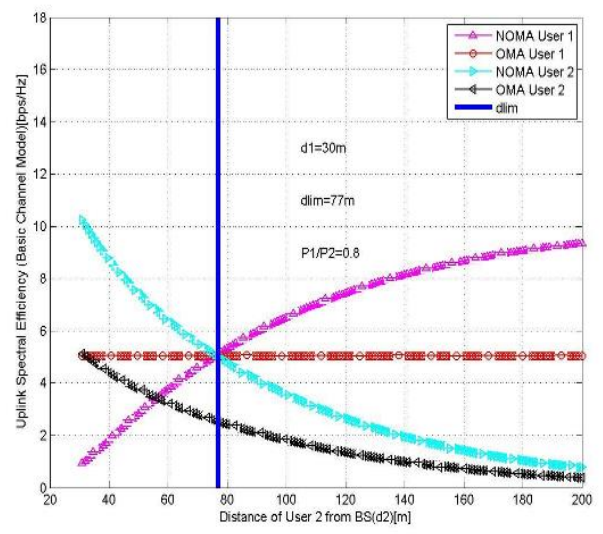

Figure 3. NOMA superiority condition for the path loss based channel model [9]

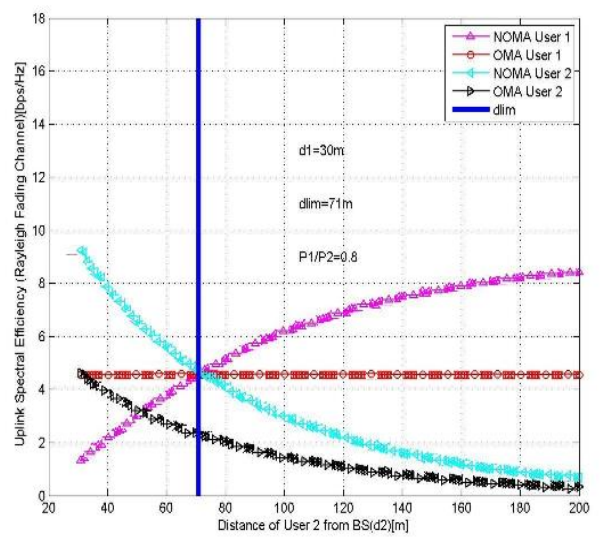

Figure 4. NOMA superiority condition for Rayleigh Fading Channel. 
In Figure 4, it can be seen that NOMA superiority condition slightly changes when Rayleigh fading channel is used. The limit value decreases $\left(\mathrm{d}_{\lim }=71 \mathrm{~m}\right)$ and NOMA superiority condition becomes $\mathrm{d}_{2}>71 \mathrm{~m}$. We conclude that for the Rayleigh channel, the gap between numerical results and the derived analytical limit distance (Equation 8) has increased. Thus, the strong user in NOMA begins to be superior to OMA at the smaller value of distance $d_{2}$. However, this difference between the distances for the superiority condition is very limited.

In OMA, there is no interference between the first user and the second user. Since SINR of the first user only depends on the distance $d_{1}$, increasing the distance $d_{2}$ does not affect its SINR and hence its spectral efficiency stays unchanged. For the second user, when distance $\mathrm{d}_{2}$ increases, SINR and spectral efficiency decreases as seen in Figure 3 and Figure 4.

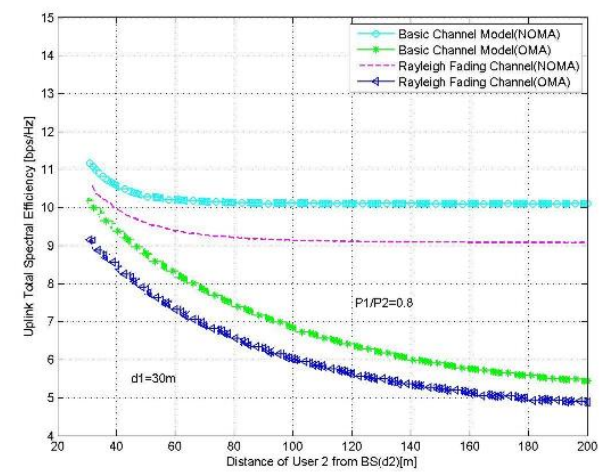

Figure 5. Sum spectral efficiencies for Rayleigh Fading Channel and Path Loss based Model in [9]

Sum spectral efficiencies for NOMA and OMA were calculated for two channel models and the results have shown in Figure 5. It can be seen that the basic channel model assumption results in higher spectral efficiency values for both NOMA and OMA channel access schemes compared to the Rayleigh fading channel model assumption. As can be seen form the Figure.5, the sum spectral efficiency of NOMA does not change for both channel models at the farther distances than NOMA superiority value $\left(\mathrm{d}_{\text {lim }}\right)$. It is because of that when the second user (the weak user) went farther from the base station, its spectral efficiency decreases, and its interference to the first user (the strong user) decreases as well. Therefore, the spectral efficiency for the first user increases while the spectral efficiency of the second user decreases as it is seen in Figure 3 and Figure 4. This opposite effect results a constant sum spectral efficiency for the distances farther than NOMA superiority distance. However, the sum spectral efficiency of NOMA is greater than the sum spectral efficiency of OMA as NOMA always outperforms OMA for the second user. In order to see the effect of power ratio on accuracy of the distance based analytical NOMA superiority condition, we obtained the $\mathrm{d}_{\text {lim }}$ distances as a function of power ratios as shown in Figure 6 and Figure 7 for both channel models. In Figure 5, it is seen that derived analytical superiority distance is very accurate but the gap between the numerical and analytical $\mathrm{d}_{\mathrm{lim}}$ values is larger for the Rayleigh channel as seen in Figure 6. For both channel models, when the transmission power ratio of the users $\left(\mathrm{P}_{1} / \mathrm{P}_{2}\right)$ gets closer to 1 , the limit value $\left(\mathrm{d}_{\text {lim }}\right)$ decreases; this means that NOMA becomes superior to OMA for smaller distances of user 2 $\left(d_{2}>d_{\text {lim }}\right)$. This is inherent results of the difference between channel gains of the users. User 1 is assumed having good channel gains while user 2 has poor channel due to its farther location. Hence, while transmission powers are getting closer to each other $\left(\mathrm{P}_{1} / \mathrm{P}_{2}=1\right)$, user 2 needs to be located in closer location to the BS to compansate its poor channel gain.

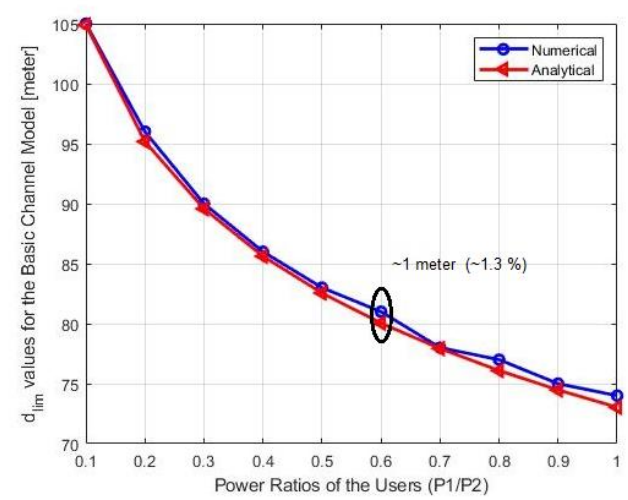

Figure 6. Boundary distance as a function of Tx power ratios for NOMA superiority condition for Path Loss based Channel model $\left(\mathrm{d}_{1}=30 \mathrm{~m}\right)$

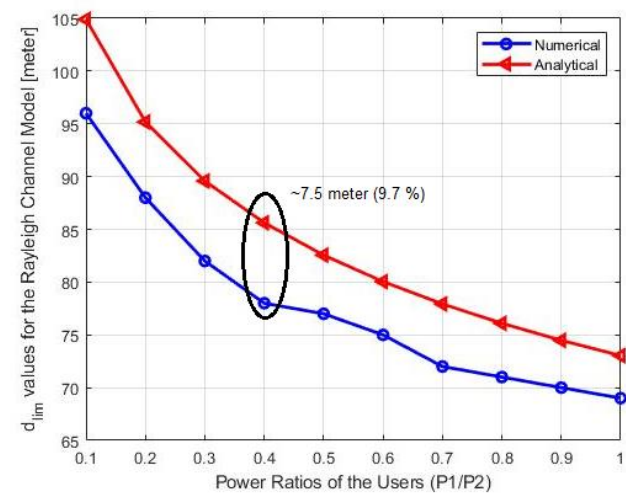

Figure 7. Boundary distance $d_{\lim }$ as a function of $T x$ power ratios for NOMA superiority condition for Rayleigh channel model $\left(\mathrm{d}_{1}=30 \mathrm{~m}\right)$. 


\section{CONCLUSION}

In this study, NOMA superiority condition is determined for the Rayleigh Channel Model and compared with the basic channel model counterpart studied in [9]. As presented in [9], the choice of the user pair that will share the same frequency is important due to the channel gain values in order to choose NOMA over OMA in terms of the spectral efficiency. In this study, we concluded that these conditions derived for NOMA superiority are also valid for the Rayleigh fading channels, but NOMA superiority condition changes according to the channel model and this change is not significant. As expected, because of neglecting the multipath fading, the basic channel model assumption studied in [9] results $\sim 1 \mathrm{bps} / \mathrm{Hz}$ higher individual and sum spectral efficiencies for both NOMA and OMA compared to the Rayleigh fading channel. NOMA provides higher spectral efficiency for the cell-edge user in both cases, because it is not affected by the cell-center user's interference due to the SIC mechanism.

Regarding the transmission power ratios of the users and the accuracy of the derived boundary distance $\left(\mathrm{d}_{\lim }\right)$ obtained from Equation 7 ; it is observed that accuracy of the analytical model is slightly changing for the basic channel model the gap between numerical values is at maximum of $\sim 1.3 \%$. However, for Rayleigh channel model the gap between analytical and numerical results has larger value at a maximum of $9.7 \%$.

Note that utilized analysis methodology consider only two user NOMA clusters, practical figure for many user NOMA clusters might be different as importance of user ranking would be come up more. As a future work, the analytical methodology for the NOMA superiority condition can be extended for more practical channel models and considering more users in the NOMA clusters.

\section{REFERENCES}

[1] Andrews J.G., Buzzi S., Choi W., Hanly S.V., Lozano A., Soong A.C.K., Zhang J.C. What will 5G be?, IEEE Journal on Selected Areas in Communications. 32:6 1065-1082, 2014.

[2] Beniebbour A., Saito Y., Kishivama Y., Li A., Nakamura T. Concept and practical considerations of non-orthogonal multiple access (noma) for future radio access. International Symposium on Intelligent Signal Processing and Communication Systems. 770-774, 2013.

[3] Hasna M.O., Alouni M.S, Bastami A., Ebbini E.S. Performance analysis of cellular mobile systems with successive co-channel interference cancellation, IEEE Transactions on Wireless Communications, 2:1 29-40, 2003.

[4] Islam S.M.R., Avazov N., Dobre O.A., Kwak K. Power-domain non-orthogonal multiple access (noma) in 5g systems: Potentials and challenges,
IEEE Communications Surveys Tutorials. 19:2, 721-742. 2017.

[5] Körpe E., Kartal B. Effect of different channel models on noma superiority condition, 3rd International Balkan Conference on Communications and Networking. 1-5, 2019.

[6] Saito Y., Kishiyama Y., Benjebbour A., Nakamura T., Li A., Higuchi K. Non-orthogonal multiple access (noma) for cellular future radio access, 77th IEEE Vehicular Technology Conference. 1-5, 2013.

[7] Prasad R. OFDM for Wireless Communications Systems, Artech, 2004.

[8] Tabassum H., Ali M.S., Hossain E., Hossain M.J., Kim D.I. Uplink Vs. Downlink NOMA in Cellular Networks: Challenges and Research Directions, IEEE 85th Vehicular Technology Conference (VTC Spring), p. 1-7, 2017.

[9] Timotheou S., Krikidis I. Fairness for non-orthogonal multiple access in $5 \mathrm{G}$ systems, IEEE Signal Processing Letters. 22:10 1647-1651, 2015.

[10] Mahady I. A., Bedeer E., Ikki S., Yanikomeroglu H. Sum-Rate Maximization of NOMA Systems under Imperfect Successive Interference Cancellation, IEEE Commun. Lett. 23 474-477, 2019.

[11] Chen Z., Ding, Z., Dai X., Zhang R. An Optimization Perspective of the Superiority of NOMA Compared to Conventional OMA, in IEEE Transactions on Signal Processing, 65:19 5191-5202, 2017.

[12] Shi Z., Ma S., ElSawy H., Yang G., Alouini M. Cooperative HARQ-Assisted NOMA Scheme in Large-Scale D2D Networks, in IEEE Transactions on Communications, 66:9 4286-4302, 2018.

[13] Sharma P., Kumar A., Bansal M. Performance analysis of downlink NOMA over $\eta-\mu$ and $\kappa-\mu$ fading channels. IET Communications, 4 522-531, 2020.

[14] Wei Z.L., Yang D.W.K., Yuan Ng,J., Hanzo L. On the Performance Gain of NOMA Over OMA in Uplink Communication Systems, in IEEE Transactions on Communications, 68:1 536-568, 2020.

[15] Mankar P.D., Dhillon H.S. Downlink Analysis of NOMA-Enabled Cellular Networks With 3GPP-Inspired User Ranking," in IEEE Transactions on Wireless Communications, 19:6 3796-3811, 2020.

[16] Tabassum H., Hossain E., Hossain J. Modeling and analysis of uplink non-orthogonal multiple access in large-scale cellular networks using poisson cluster processes, IEEE Transactions on Communications. 65:8 3555-3570, 2017

[17] Z. Shi, S. Ma, H. ElSawy, G. Yang and M. Alouini, "Cooperative HARQ-Assisted NOMA Scheme in Large-Scale D2D Networks," in IEEE Transactions on Communications, 66:9 4286-4302, 2018.

[18] Salehi M., Tabassum H., Hossain E. Accuracy of Distance-Based Ranking of Users in the Analysis of NOMA Systems, in IEEE Transactions on Communications, 67:7 5069-5083, 2019. 